\title{
BUDGETING, BUDGETARY CONTROL AND PERFORMANCE EVALUATION: EVIDENCE FROM HOSPITALITY FIRMS IN NIGERIA
}

\author{
Patrick Amaechi Egbunike \\ Department of Accountancy, Nnamdi Azikiwe University, Awka, Anambra State, Nigeria \\ amaechiegbunike@yahoo.com \\ Amaka Nkiru Unamma \\ PhD. Student, Department of Accountancy, Nnamdi Azikiwe University, Awka, Anambra \\ State, Nigeria \\ amakaunamma@gmail.com
}

\begin{abstract}
This study was carried out with the view to address two fundamental issues: first, to determine if there is any association between budget, budgetary control and performance evaluation; second, to ascertain if there is any significant variation in the budget, budgetary control and performance evaluation measures of hospitality firms in Nigeria. The study employed descriptive design and primary data (questionnaire) was the major source of data collection. Questionnaire was administered to a total of six hundred (600) employees of ten (10) selected hospitality firms in Nigeria. The data obtained were analyzed using both descriptive and inferential statistics. Findings indicated that budget and budgetary control could serve as an avenue through which hospitality firms in Nigeria can be evaluated. In addition, it was revealed that there is a significant variation in the budget, budgetary control and performance evaluation of hospitality firms in Nigeria. On the basis of the findings, it was recommended that hospitality firms in Nigeria should carry out performance evaluation on every aspect of their budget and budgetary activities as a way of ensuring that budgeted outcomes are met. Also, budgetary costs should be a basis of choosing the most-fit performance evaluation technique for hospitality firms since such performance evaluation systems can provide economic benefits of different sorts to them.
\end{abstract}

\section{Keywords:}

budgeting; budgetary control; hospitality companies; performance; evaluation techniques; budgeted outcome; actual outcomes; costs

\section{JEL Classification}

H61; H69; H83

\section{Introduction}

In economic principle, there is the general assumption that human wants are numerous but the resources to satisfy them are inadequate and there is every tendency to waste or under-utilize the inadequate resources by human factor concerned in the production of goods and services. It is imperative for organizations to produce at a minimum cost so as to continue their production cycles and make sufficient revenues for stakeholders. This scenario is peculiar to all industries in Nigeria, especially those of the hospitality companies industry where strategies are needed in order to survive. The hospitality industry is a broad class of fields within the service industry that encompasses lodging, event planning, theme parks, transportation, cruise lines and so on. Thus, hospitality management needs an effective tool that can help them forecast the major changes which are likely to affect the organization both in the present and future. Budgeting, which is a tool of planning and control, becomes indispensable for the hospitality companies in Nigeria and the world over. 
According to Lambe, Lawal and Okoli (2015), budgeting is a key policy instrument for public management and management of firm; it is a familiar activity to many as it is practiced in our private lives as well as in businesses, government and voluntary groups. The Chartered Institute of Management Accountants (CIMA) (2000) sees budget as a financial or qualitative statement prepared and approved prior to a defined period of time for the purpose of attaining a specified objective. Egbunike (2014) believes that budget is a comprehensive and coordinated plan expressed in financial terms for the operations of an enterprise for some specific period in the future. Lucey (2003) defined a budget as a quantitative expression of a plan of action prepared for an organization as a whole in order for them to carry out certain functions such as sales and production or for financial resources items such as cash, capital expenditure, man-power purchase and others.

Budgetary control as noted by the Institute of Cost and Management Accountants (1998) is the establishment of budgets relating the responsibilities of executives to the requirements of a policy and the continuous comparisons of actual with budgeted outcomes, either to secure by individual action, the objectives of that policy, or to provide a basis for its revision. In the same vein, Batty (1982) sees budgetary control as a system which utilizes budget as a means of planning and controlling all aspects of the organization. The philosophy underlying budget and budgetary control therefore is that they serve as indicators of costs and revenues linked to the daily operational activities of project managers, a means of providing information and supporting management decisions throughout the year and monitoring and controlling the organization, particularly in analyzing the differences between the budgeted and actual. Consequently, budgeting and budgetary control are needed for evaluating the performance of an organization. On the basis of the above, this study was carried out with the view to address two fundamental concerns: first, to determine if there is any relationship between budget/budgetary control and performance evaluation of hospitality companies in Nigeria; second, to ascertain if there is any significant variation in the budget, budgetary control and the performance evaluation among hospitality companies in Nigeria. In order to address these two fundamental concerns, we hypothesized as follows:

$\mathrm{H}_{\mathrm{o}}$ : There is no significant association between budget, budgetary control and the performance of hospitality companies in Nigeria.

$\mathrm{H}_{2}$ : There is no significant variation in the budget, budgetary control and the performance evaluation among hospitality companies in Nigeria.

\section{Review of Related Literature}

In this paper, the review of related literature encompassed the conceptual issues and theoretical framework.

\section{Conceptual Issues}

\section{a. The Concept of Budget and Characteristics}

Omolehinwa (2002) sees budget as a plan in an organization expressed in monetary terms and subject to the constraints imposed by the participants and the environments, indicating how the available resources of the organization may be utilized in order to achieve whatever the objectives of the organization. According to Brown and Howard (2002), it is a predetermined statement of management policy during a given period which provides a standard for comparison with results actually achieved. Also, Buyers and Holmes (1984) defined budget as a financial and/or quantitative statement prepared and approved prior to be pursued during that period for the purpose of attaining a given objective. To Cope (1994), it is a comprehensive plan expressed in financial terms by 
which an operating programme is effective for a given period of time (usually one year) including estimates of the services, activities and projects comprising the programme, resultant expenditure requirement and the resources usable for their support.

Laynetwor (2004) posits that budgeting is the only comprehensive approach to managing an organization and if utilized with sophistication and good judgment, the objectives of the organizations can be achieved. Budget recognizes fully, the dominant role of managers and provides a framework for implementing the fundamental aspects of scientific management as management by objectives (MBO), effective communication, participative management, dynamic control, continuous feedback, responsibility accounting, management by exception and management flexibility. Therefore, a good budget may be characterized with the following attributes:

- Participation - It involves as many people as possible in drawing up a budget;

- Comprehensiveness - It embraces the whole organization;

- Standards - It is based on established standards of performance;

- Flexibility - It gives room for changing circumstances;

- Feedback - It constantly monitor performance; and

- Analysis of Cost and Revenue - Allows cost and revenue analysis on the basis of product lines, departments or cost centres.

\section{b. The Concept of Budgetary Control}

Budgetary control can be viewed as a system of controlling cost which embraces the preparation of budget, coordinating the department and establishing responsibility, comparing actual performance with budgeted and acting upon results to achieve maximum profitability (Brown \& Howard, 2002). As observed by Lockyer (1983), budgetary control is a part of the overall system of responsibility accounting within an organization, as costs and revenues are analyzed in accordance with areas of personal responsibilities of the budget holders through permitting financial monitoring. The Chartered Institute of Management Accountants (2000) sees budgetary control as the process of comparing the actual outcomes with the planned outcomes and reporting on the variations.

There are basic stages in budgetary control processes and they include setting of predetermined standards, measurement of actual performance against pre-determined standards and corrective measures if necessary to bring the actual performances in line with the pre-determined standard. Thus, the overall purpose of budgetary control is to assist managers' plan and control the use of resources in systematic and logical manner to ensure that they achieve their financial objectives. For budgetary control to be effective, the following essentials/features must be in place:

- A sound and clearly defined organization with a clearly defined manager's responsibility;

- An effective accounting record keeping and procedures;

- Support and commitment of top management for the budgetary control system in place;

- Training of managers in the development, interpretation and use of budgets; and

- Flexibility of budgets to ensure revision of budgets where amendments are needed to make them appropriate and useful.

\section{c. Overview of Performance Evaluation}

Performance evaluation is pivotal to an organization such that it can be used to ascertain if the budget and budgetary control instituted achieves the expected outcomes during a specified period of time. Performance evaluation is a tool for appraising how well an organization has performed. In order to appraise such organizations, managers need to determine what an organization is supposed to accomplish. According to Egbunike 
(2014), the evaluation process may consist of two variables: organizational performance data and benchmark that creates a framework for evaluating performance. The benchmark has to do with the standards based on performance of similar agencies/industrial standards/political expectations.

The whole aim of performance evaluation therefore is to determine how efficient an organization is able to put into use, the resources at its disposal. Efficiency is determined by observing performance output and outcome achieved considering the number of people involved in the process (productivity per person) and cost data (capturing direct cost as well as indirect). Performance evaluation can also be utilized to validate business successes, justifying additional resources, earning customers, stakeholders and staff loyalty and win recognition inside and outside the organization (Siyanbola, 2013).

\section{Theoretical Framework}

There are numerous theories that can be used to explain budget and budgetary controls: Walker's progressive theory, the Principal-agent model and budget theory, Punctuated equilibrium theory of budgeting among others. However, the theoretical framework of this paper was premised on the above three theories.

\section{a. Walker's Progressive Theory}

Walker was concerned with the standard of living in cities and the ability to pay for it. Walker's progressive budget theory centered on the premise that the means to decide how to allocate between options was through the "Utilitarian ideal" or indifference point in economic theory as applied to government budgets. Walker advanced her belief that the ideal of marginal utility was desirable, but it needed to be applied according to the progressive - values" or "human nature values (Beckett, 2002).

\section{b. The Principal-Agent Model and Budget Theory}

At the heart of public budgeting are relationships among those who provide agency services and those who allocate resources to service providers. In order words, those who make claims on governmental resources are agents and those who allocate and ration the resources are principals. In this relationship, the principals contract with agents to provide services to the public, and the main focus for all those involved is the contract (i.e. the budget) itself (Forrester, 2002)

\section{c. Punctuated Equilibrium Theory of Budgeting}

Baumgartner and Jones (1993) established their concept of "punctuated equilibria" that addresses both incremental and large budget changes. It asserts that there is a state of equilibrium followed by a punctuated change followed again by equilibrium. The state of equilibrium is during quiet periods of incremental change. Punctuations are breaks from the equilibrium norm. Punctuated equilibrium theory involves environments of stability shifting into environments of instability (Jordan, 2002). Thus, in order to establish equilibrium in terms of budget changes, the budget and budgetary control measures put in place by an entity becomes pivotal to the overall performance system of ensuring stability of environment. On the basis of the above theories, we provided a theoretical model for the study below: 


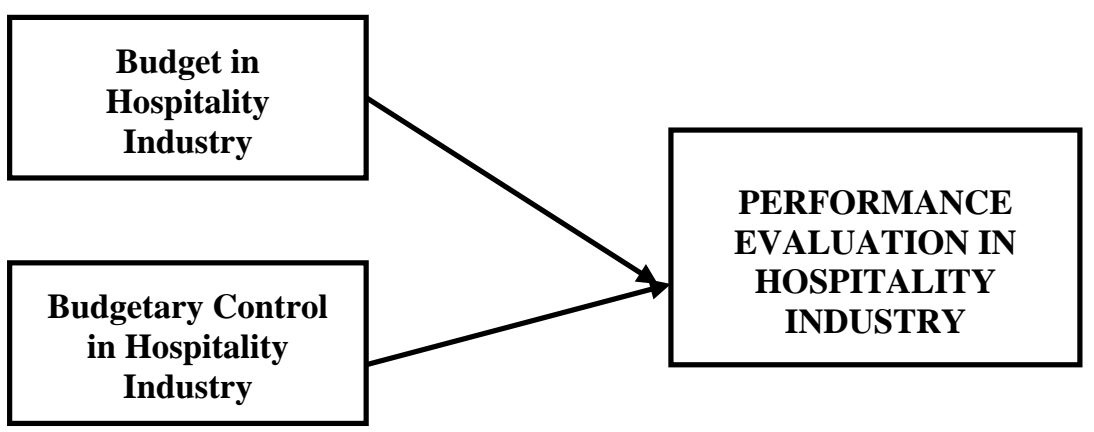

Figure 1. Theoretical Model

\section{Methods}

This study employed descriptive design and primary data was the major source of data collection. Primary data was collected through the use of semi-structured questionnaires and was developed with five-point scale rating. The ratings for each category is Strongly Agree (5), Agree(4), Not Sure(3) and Disagree (2) Strongly Disagree(1). Primary data was mainly employed due to the fact that it was impossible to access the performance data of hospitality companies in Nigeria. The Cronbach alpha reliability coefficient technique was used to establish the internal consistency of the research instrument.

Thirty (30) respondents who are not from the study area constitute the test group and yielded a Cronbach Alpha of 0.76. The population of the study covered all hospitality companies. However, ten hospitality companies were purposively selected as the sample of the study. In view of the fact that management and supervisors participate in the budgeting process, questionnaires were distributed mainly to these groups and these formed the respondents of the study. Thus, a total of six hundred (600) questionnaires were administered on a face-to-face basis so as to facilitate immediate return of the completed questionnaires and ensured an unbiased sampled population.

The questionnaire obtained were analyzed using both descriptive (frequency counts, mean and standard deviation) and inferential statistics (Pearson correlation and t-test). Mean and standard deviation was used to validate the items in the questionnaire. A mean above 2.50 is valid for such questionnaire item. On the other hand, the Pearson correlation was employed in order to ascertain the association between budgeting, budgetary control and the performance of hospitality companies in Nigeria and the ttest was used to ascertain if there exists, any significant variation in the budget/budgetary controls and performance evaluation techniques employed by hospitality companies in Nigeria.

\section{Results}

First, we reported the frequency counts with respect to the departments of the respondents; second, we analyzed the mean and standard deviation responses; and third, Pearson correlation and t-test result in line with the hypotheses of the study was done. 

FIRMS IN NIGERIA

Table 1. Departments of the Respondents

\begin{tabular}{|lcc|}
\multicolumn{1}{c}{ Department } & Frequency & Percentage \\
\hline Administrative & 144 & $24.0 \%$ \\
\hline Accounts & 177 & $29.5 \%$ \\
\hline Front Office/Desk & 89 & $14.8 \%$ \\
\hline Food/Beverages & 65 & $10.8 \%$ \\
\hline House Keeping & 80 & $13.3 \%$ \\
\hline Maintenance & 45 & $7.5 \%$ \\
\hline TOTAL & 600 & $100 \%$ \\
\hline
\end{tabular}

Table 1 captures the frequency counts with respect to the departments of the sampled hospitality companies used in the study. It is evident that 144 (24.0\%) and 177 (29.5\%) of the respondent sampled were from administrative and accounts departments respectively while $89(14.8 \%)$ and $80(13.3 \%)$ from front office/desk and housekeeping departments respectively. Only 65 (10.85) and $45(7.5 \%)$ were sampled from Food/Beverages and Maintenance.

\section{Table 2. Mean Scores of Budget, Budgetary Control and Performance Evaluation $(\mathbf{N}=600)$}

\begin{tabular}{|clccc|}
\hline S/N & \multicolumn{1}{c}{ Items } & Mean & SD. & Decision \\
\hline 1 & $\begin{array}{l}\text { Budgets motivate managers to achieve } \\
\text { objectives and thereby establish control } \\
\text { within the organization }\end{array}$ & 3.18 & .880 & Valid \\
\hline 2 & $\begin{array}{l}\text { Budget committee exists within the } \\
\text { organization }\end{array}$ & 3.36 & .840 & Valid \\
\hline 3 & $\begin{array}{l}\text { Budgeting process is duly followed by } \\
\text { management }\end{array}$ & 3.30 & .830 & Valid \\
\hline 4 & $\begin{array}{l}\text { Budgetary controls assist management assess } \\
\text { the level of performance }\end{array}$ & 3.54 & .840 & Valid \\
\hline 5 & $\begin{array}{l}\text { Budgetary controls contribute positively to } \\
\text { the performance of your organization }\end{array}$ & 3.28 & .820 & Valid \\
\hline 6 & $\begin{array}{l}\text { Budgeting has assisted organization in } \\
\text { making optimal use of its resources }\end{array}$ & 3.11 & .960 & Valid \\
\hline 7 & $\begin{array}{l}\text { Need for proper training of managers before } \\
\text { they can effectively utilize budgetary control } \\
\text { techniques }\end{array}$ & 3.29 & .830 & Valid \\
\hline 8 & $\begin{array}{l}\text { Budgetary control is an effective mechanism } \\
\text { for financial planning and control }\end{array}$ & 3.31 & .860 & Valid \\
\hline 9 & $\begin{array}{l}\text { Internal control is a tool for effective } \\
\text { budgetary control? }\end{array}$ & 3.29 & .830 & Valid \\
\hline 10. & $\begin{array}{l}\text { Every profit-making organization should have } \\
\text { effective budgeting and budgetary control }\end{array}$ & 3.67 & .870 & Valid \\
\hline & GRAND MEAN & $\mathbf{3 . 3 3}$ & $\mathbf{8 5 5}$ & Valid \\
\hline & \begin{tabular}{ll} 
Source: Field Work, 2017 \\
\hline
\end{tabular} & & & \\
\hline
\end{tabular}

Table 2 shows the mean scores of budget, budgetary control and performance evaluation. However, the mean result revealed that all the 10 -itemed questions scored above the benchmark of 2.50. Also, item 10 have the highest mean score of 3.67 with 
standard deviation of .870 . This means that every profit-making organization should have effective budgeting and budgetary control. However, items 1, 2, 3, 4, 5, 6, 7, 8 and 9 have their means within the range of 2.50-3.49. This means that all the items are useful in establishing the association between budget, budgetary control and performance evaluation of hospitality companies in Nigeria. This position was further supported by the grand mean of 3.33 and standard deviation of .855 which is also above the 2.50 benchmark.

Table 3. Pearson Correlation for Budget, Budgetary Controls and Performance Evaluation (N600)

\begin{tabular}{|llllllll|}
\hline \multicolumn{1}{|c}{ Variables } & $\begin{array}{l}\text { Mean } \\
\text { Score }\end{array}$ & SD & VIF & Tol & t-cal & t-tab & df \\
\begin{tabular}{|l} 
Budget \& Budgetary \\
Control (N=600)
\end{tabular} & 19.62 & 4.4 & 1.00 & 1.00 & 0.79 & 0.19 & 598 \\
\cline { 1 - 2 } $\begin{array}{l}\text { Performance } \\
\text { Evaluation (N=600) }\end{array}$ & 15.08 & 6.52 \\
\hline
\end{tabular}

The result as summarized in table 3 shows that the calculated Pearson correlation value of 0.79 is greater than the tabulated value of 0.19 . Therefore, the null hypothesis is rejected and the alternative hypothesis which states that there is significant association between budget, budgetary control and the performance of hospitality companies in Nigeria is accepted. This implies that budget and budgetary controls can be employed as a mean of evaluating the performance of hospitality companies in Nigeria.

\section{Table 4. T-test Result of Budget, Budgetary Control $\&$ Performance Evaluation $(\mathrm{N}=600)$}

\begin{tabular}{|c|c|c|c|c|c|c|}
\hline & \multicolumn{6}{|c|}{ Test Value $=2$} \\
\hline & \multirow[t]{2}{*}{$\mathbf{T}$} & \multirow[t]{2}{*}{ df } & \multirow[t]{2}{*}{$\begin{array}{l}\text { Sig. (2- } \\
\text { tailed) }\end{array}$} & \multirow[t]{2}{*}{$\begin{array}{c}\text { Mean } \\
\text { Difference }\end{array}$} & \multicolumn{2}{|c|}{$\begin{array}{l}95 \% \text { Confidence } \\
\text { Interval of the } \\
\text { Difference }\end{array}$} \\
\hline & & & & & Lower & Upper \\
\hline $\begin{array}{l}\text { Budget/Budgetary } \\
\text { Control }\end{array}$ & 4.819 & 2 & .001 & 118.69167 & 64.4817 & 172.9016 \\
\hline $\begin{array}{l}\text { Performance } \\
\text { Evaluation }\end{array}$ & 4.621 & 2 & .001 & 132.92917 & 69.6192 & 196.2391 \\
\hline
\end{tabular}

The p-value is 0.001 and therefore, the difference between the two means is statistically significantly different from zero at the $5 \%$ level of significance. However, there is sufficient evidence $(p=0.001)$ to suggests that on the average, the sampled hospitality companies on the variation in the budgeting, budgetary control varies as regards to performance evaluation. This result is supported by the computed $t$-values (budget/budgetary control 4.819 and performance evaluation: 4.621) which is significantly higher than the tabulated value (t-tab: 1.660). This led to the rejection of the null hypothesis and acceptance of the alternative hypothesis that there is a significant variation in the budget, budgetary control and the performance evaluation among of hospitality companies in Nigeria. 


\section{Conclusion}

Performance evaluation is fundamental to every profit-making organization in that it can be employed as a means of ascertaining if the budget/budgetary control measures of organizations achieve the expected results during a specified time-span. Thus, performance evaluation is a tool for appraising how well an organization has performed. Consequently, this study was carried out with the view to address two fundamental issues: first, to determine if there is any association between budget/budgetary control and performance evaluation of hospitality companies in Nigeria; second, to ascertain if there is any significant variation in budget/budgetary control and performance evaluation measures among hospitality companies in Nigeria. The study employed descriptive design and primary data (questionnaire) was the major source of data collection which was administered to a total of six hundred (600) employees of ten (10) selected hospitality companies in Nigeria.

The analysis of the study revealed that all the items in the questionnaire were useful in establishing the association between budget/budgetary control and performance evaluation among hospitality companies. More interestingly, it was found that budget/budgetary control is a means of evaluating the performance of hospitality companies in Nigeria. Furthermore, it was revealed that there is a significant variation in the budget/budgetary control and the performance evaluation of hospitality companies in Nigeria. On the basis of the findings, it was recommended that hospitality firms in Nigeria should carry out performance evaluation on every aspect of their budget and budgetary activities as a way of ensuring that budgeted outcomes are met. Also, budgetary costs should be a basis of choosing the most-fit performance evaluation technique for hospitality firms since such performance evaluation systems can provide economic benefits of different sorts to them.

\section{References}

Batty, J. (1982). Management accounting. London: Macdonald and Evans Ltd.

Beckett, J. (2002). Early budget theory: The progressive theory of public expenditure in Khan, A. and Hildreth, W.B (Eds.). budget theory in the public sector. London: Quorum Books.

Brown J.L. \& Howard, L.R. (2002). Principles and practice of management accounting. London: MacDonald and Evans Ltd.

Buyers \& Holmes. G (1987). Principles of cost accounting, ( $4^{\text {th }}$ ed.). United States: Cassel Limited.

Chartered Institute of Management Accountants (2000). Management accounting official terminologies. CIMA.

Cope, O.K. (1994). Operations analysis: The basis for programme budgeting, performance budgeting and unit cost accounting for government unit. USA: Chicago Press.

Egbunike, P.A (2014). Management accounting techniques and applications. (Revised edition), Anambra: Nimo-Rex Charles and Patrick Limited.

Forrester, J. (2002). The principal-agent model and budget theory in Khan, A. and Hildreth, W.B (Eds.) budget theory in the public sector. London: Quorum Books.

Institute of Cost and Management Accountants (1998). Financial operations in a developing economy. ICAN News .

Jordan, M.M. (2002). Punctuated equilibrium: An agenda-based theory of budgeting in Khan, A. and Hildreth, W.B (Eds.) budget theory in the public sector. London: Quorum Books. 
Lambe, I., Lawal, M., \& Okoli, T. ( 2015). A systematic review of budgeting and budgetary control in government owned organizations. Research Journal of Finance and Accounting, 6(6), 1-10.

Laynetwor, A. (2004). Budgeting and budgetary controls, (2 ${ }^{\text {nd }}$ ed.). Auckland: Blue Shark Press Limited.

Lockyer, K. (1983). Fundamental of budget preposition ethics: A development. New York: McGraw-Hills Book Company

Lucey, T. (2003). Management accounting. New York: DP Publication.

Omolehinwa, (2002). Work-out management accounting, ( $2^{\text {nd }}$ ed.). Great Britain: Handmann Publishing.

Siyanbola, T.T. (2013). The impact of budgeting and budgetary control on the performance of manufacturing company in Nigeria. Journal of Business Management and Social Sciences Research, 2(12), 8-16. 